\title{
Urgensi Transformasi Pemerintahan Demokrasi Menuju Pemerintahan Islam
}

\author{
Suteki ${ }^{1 *}$ \\ ${ }^{1}$ Program Studi Ilmu Hukum, Fakultas Ilmu Hukum, Universitas Diponegoro, Semarang, Indonesia
}

ARTICLE INFO

ABSTRACT

\begin{abstract}
Transformasi sering dipakai dalam arti suatu upaya perubahan agar terjadi penyesuaian hukum dengan kebutuhan masyarakatnya. Mentransformasikan hukum baik dalam bentuk sistem maupun Peraturan Perundang-undangan yang baik dibutuhkan sekurang-kurangnya empat landasan yakni: landasan filosofis, sosiologis, yuridis. Di Indonesia, pergolakan pemikiran tentang hukum sebenarnya sudah dimulai pada saat berdirinya kerajaan-kerajaan primitif di nusantara. Namun demikian, hal ini sulit dilacak keberadaannya, kecuali dengan pendekatan arkeologi yang ketat dan memakan waktu tak sedikit itu. Penelitian deskriptif ini akan memaparkan bagaimana implementasi hukum positif di indonesia pada pra dan pasca kemerdekaan untuk dikomparasikan dengan hukum Islam. Meskipun hukum adat yang mencirikan khas keindonesiaan pernah menjadi salah satu tawaran terbaik, pada kenyataannya juga masih mudah terjebak pada paradigma yang lama, yakni positivisme hukum. Hukum tersebut tidak semestinya terjebak pada paradigma positivistik-legalistikformalistik, yang menempatkan hukum sebagai benda mati. Secara teoretis memang sangat dimungkinkan hukum Islam sebagai sumber hukum utama dalam pembangunan dan pengembangan hukum di Indonesia, namun secara praktis hukum Islam hanya dijadikan landasan untuk mengatur hukum keluarga saja. Hukum Islam akan menjadi sumber utama hukum bila negara itu memiliki sistem pemerintahan Islam, tidak lain sistem khilafah.
\end{abstract}

\section{PENDAHULUAN}

Dalam bidang hukum, transformasi ${ }^{1}$ juga sering dipakai dalam arti suatu upaya perubahan agar terjadi penyesuaian hukum dengan kebutuhan masyarakatnya. Terkait dengan artikel ini judul artikel ini dapat diartikan sebagai proses atau upaya transformasi hukum pemerintahan demokratis (tata hukum nasional) ke dalam tata hukum Islam dimaksudkan sebagai usaha menerapkan hukum Islam yang hingga kini masih bersifat sebagai living law menjadi hukum Islam yang positif atau yang sering disebut usaha mempositifkan hukum Islam ke dalam tata hukum Indonesia, atau setidak-tidaknya menjadikan hukum Islam sebagai sumber utama pembuatan hukum nasional di Indonesia.

Sebagaimana diketahui bahwa dunia ini pantharich, terus mengalir, berubah tanpa henti, begitu kata philosof Yunani, Heracleitos (500 SM). Perubahan terus terjadi yang terus pula menanyakan arti sebuah keabadian. Adakah keabadian itu? Atau justru apakah perubahan itu merupakan keabadian? Tatkala dalam perkembangan filsafat dan teori-teori ilmu pengetahuan sosial setelah abad pertengahan, para pemikir di negeri-negeri Eropa Barat semakin memantapkan keyakinan akan kebenaran paradigma harmoni yang dinamik. Konsekuensi logisnya adalah termantapkannya pula ide progresivisme dalam kehidupan manusia itu. Paradigma ini, berseiring dengan kian populernya konsep Galilean-Newtonian ${ }^{2}$ mengenai tertib semesta yang universal ini (untuk menggeser ke pinggiran konsep Aristotelian-Leibnizian ${ }^{3}$ ), menjadikan analisis-analisis empirik-induktif menjadi kian tambah populer dalam dunia pemikiran di Barat. Berdasarkan konsep Galilean-Newtonian maka tak ada di alam

\footnotetext{
${ }^{1}$ Berdasar KBBI, kata transformasi diartikan (1) perubahan rupa (bentuk, sifat, fungsi, dan sebagainya). (2) dalam pengertian ketatabahasaan berarti perubahan struktur gramatikal menjadi struktur gramatikal lain dengan menambah, mengurangi, atau menata kembali unsur-unsurnya. Mentransformasikan berarti (1) mengubah rupa (bentuk, sifat, fungsi, dan sebagainya) (2) mengalihkan: Pemerintah berhasil mentransformasikan benteng itu menjadi objek pariwisata. Berdasar definisi KBBI tersebut dapat dinyatakan bahwa transformasi merupakan suatu usaha untuk mengadakan perubahan terhadap sesuatu yang telah ada menjadi sesuatu yang baru, antara lain dengan penyesuaian dan perubahan dalam rangka untuk melakukan penataan kembali.

${ }^{2}$ Konsep Galilean-Newtonian merupakan rumpun sains dengan ciri chaos, mekanistik kausal, cause and effect, acak. Sains ini mencoba untuk memahami alam semesta ini tidak lagi sebagai suatu harmonious pre-established order melainkan sebagai suatu keadaan chaos, penuh proses yang mengungkapkan berbagai kemungkinan hubungan kausal mekanis antar unsur variable.

${ }^{3}$ Konsep Aristotelian-Leibnizian merupakan rumpun sains dengan ciri pre-established harmonious order, causa finalis. Sains ini mencoba untuk memahami alam semesta ini sebagai suatu harmonious pre-established order, semesta diciptakan oleh Tuhan Yang Maha Kuasa sebagai sesuatu rancangbangun tatanan yang bersifat final dan harmoni serta sempurna sejak awal mulanya.
} 
semesta ini yang bersifat abadi, perubahan adalah suatu keniscayaan berdasarkan prinsip cause and effect yang bersifat acak. Kata Longfellow: "All must change to something new and to something strange". Jatuh bangun, keambrukan demi keambrukan sebuah sistem bahkan sebuah paradigma akan terus terjadi, sehingga transformasi dalam setiap lini kehidupan juga tak akan dapat dihindarkan lagi.

Mentransformasikan hukum baik dalam bentuk sistem maupun Peraturan Perundang-undangan yang baik dibutuhkan sekurang-kurangnya empat landasan yakni: landasan filosofis, sosiologis, yuridis---seperti layaknya pembuatan suatu peraturan undang-undang. Di samping ketiga landasan tersebut, maka ada satu landasan penting yakni landasan politis. Landasan filosofis berisi nilai-nilai moral atau etika dari bangsa tersebut. Moral dan etika pada dasarnya berisi nilai-nilai yang baik dan yang tidak baik, sedangkan nilai yang baik merupakan pandangan dan cita-cita yang dijunjung tinggi yang di dalamnya ada nilai kebenaran, keadilan dan kejujuran serta berbagai nilai lainnya yang dianggap baik.

Landasan yuridis adalah landasan hukum yang menjadi dasar kewenangan pembentukan dan perubahan hukum. Landasan sosiologis, ketentuan-ketentuannya harus sesuai dengan keyakinan umum atau kesadaran hukum masyarakat. Hal ini penting agar perundang-undangan yang dibuat ditaati oleh masyarakat. Adapun landasan politis merupakan garis kebijaksanaan politik yang menjadi dasar selanjutnya bagi kebijaksanaan-kebijaksanaan dan pengarahan ketatalaksanaan pemerintahan negara. Produk hukum sangat dipengaruhi - bahkan ditentutakan - oleh pemegang kekuasaan politik. Maka, tampak di sana bahwa konstruksi politik setiap penguasa akan mempengaruhi corak dan karakter hukum. Sebagaimana telah diteliti oleh Mahfud MD. ${ }^{4}$

\section{IMPLEMENTASI HUKUM POSITIF DI INDONESIA (PRA DAN PASCA KEMERDEKAAN)}

Perkembangan struktur sosial terkait dengan tipe hukum yang dipakai di Indonesia dapat dikatakan tidak evolutif atau dapat dikatakan " $a$-history". Secara ringkas, kaitan antara perkembangan struktur sosial dengan perkembangan hukum dapat dijelaskan pada Gambar 1.

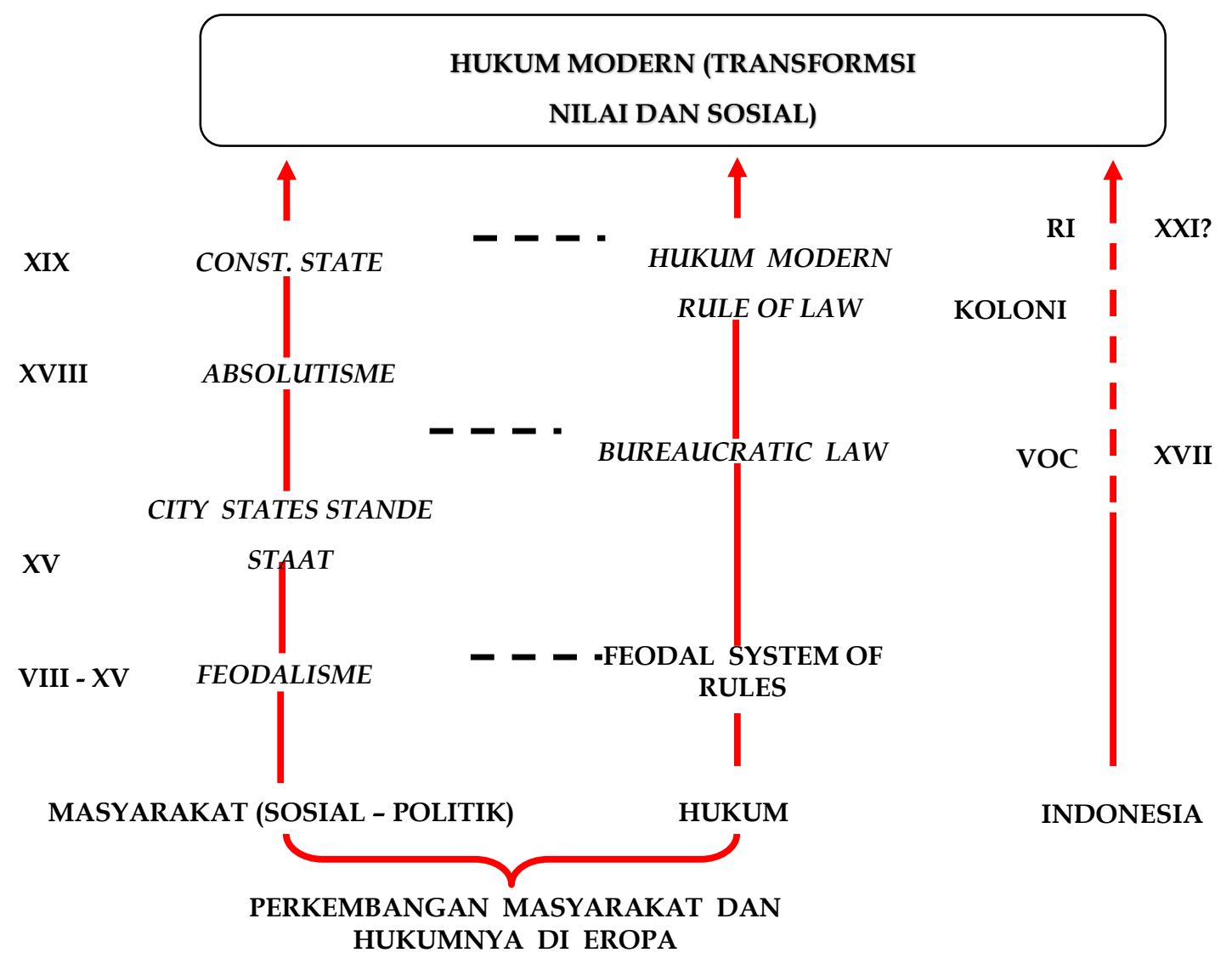

Gambar 1. Kaitan antara perkembangan struktur sosial dengan perkembangan hukum

Pada awal perkembangannya Indonesia memiliki karakteristik struktur sosial yang hampir sama dengan struktur sosial di Eropa. Jadi masa feodalisme Indonesia juga mengalaminya, terutama pada jaman kerajaan dahulu. Kemudian sejak datangnya VOC pada abad 17, perkembangan struktur sosial tersebut seakan tertahan (arrested) oleh desakan penggunaan hukum Eropa (yang diadopsi oleh Belanda (VOC)). Meski secara teori pribumi juga diberi kesempatan untuk tetap menggunakan hukum adat (pribumi) namun secara diam-diam banyak pribumi yang secara sukarela tunduk pada hukum Eropa tersebut.

Di Indonesia, pergolakan pemikiran tentang hukum sebenarnya sudah dimulai pada saat berdirinya kerajaan-kerajaan primitif di nusantara. Namun, hal ini sulit dilacak keberadaannya, kecuali dengan pendekatan arkeologi yang ketat dan memakan waktu tak sedikit itu. Situs-situs teks dapat ditemukan misalnya dengan epos Nāgara Krtāgama. ${ }^{5}$ Kejayaan Majapahit nampaknya tidak

\footnotetext{
${ }^{4}$ Mahfud, MD. Politik Hukum di Indonesia (Jakarta: LP3ES, 2001) cet. Ke-2, hlm. 15.

${ }^{5}$ Mpu Tantular. Kakawin Desa Warnnana Uthawi Nãgara Krtāgama. Diterjemahkan oleh Prof. Dr. Drs. I Ketut Riana, SU. Masa Keemasan Majapahit. 2009. Kompas. Jakarta.
} 
JKPIs, Vol. 1 No. 1, 2018 | 30

hanya laksana dongeng negeri 1001 malam saja, melainkan sebuah realitas historis yang terus mengundang sejuta tanya. Bagaimana pemikiran hukum di masa itu. Bahkan van Vollenhoven, yang melakukan studi literatur berpuluhan tahun tentang hukum adat di Indonesia menjelaskan bahwa pada masa Majapahit, sebuah kodifikasi hukum sudah berlangsung di bawah kekuasaan Patih Gadjah Mada, kitab undang-undang tersebut itu juga diberi namanya. Namun setelah ia meninggal, Hayam Wuruk pun tiada, sistem hukum Majapahit mulai carut-marut lengkap dengan perang saudaranya. Konstruksi historis hukum Majapahit menggambarkan sekian risalah sejarah hukum kerajaan-kerajaan Indonesia yang tersebar dari berbagai tempat dan lintasan waktu hingga munculnya hukum modern kolonial yang dibawa oleh Eropa.

Kerajaan-kerajaan Hindu-Buddha surut, mulai berdiri kerajaan-kerajaan Islam di tanah air kita. Agama Islam mulai masuk ke Indonesia pada abad ke-13 M. Agama dan kebudayaan Islam masuk Indonesia melalui para pedagang yang berasal dari Arab, Persia, dan Gujarat (India), dan Cina. Agama Islam berkembang dengan pesat di tanah air. Hal ini dapat dilihat dengan berdirinya kerajaan-kerajaan Islam. Kerajaan Islam yang pertama kali berdiri di Sumatra dan tanah air adalah Kerajaan Perlak (Peureula). Kerajaan Perlak ini berdiri pada pertengahan abad IX dengan raja pertamanya bernama Alauddin Syah. Perlak pada saat itu merupakan kota dagang penyedia lada paling terkenal. Pada akhir abad XII Kerajaan Perlak akhirnya mengalami kemunduran. Seperti halnya Kerajaan Ternate, Kerajaan Tidore pun merupakan penghasil cengkeh yang besar. Berkat hasil cengkehnya itu kerajaan Tidore menjadi kerajaan yang maju. Raja yang terkenal di Kerajaan Tidore adalah Sultan Nuku. Pada masanya, kekuasan Tidore meliputi Halmahera, Seram, Kai, dan Irian Jaya. Pada mulanya kerajaan Ternate dengan Kerajaan Tidore hidup damai berdampingan. Namun sejak kedatangan Portugis, kedua kerajaan ini di adu dombakan, setelah mengetahui bahwa Portugis ingin menguasai Maluku, akhirnya dua kerajaan ini bersatu dan mengusir Bangsa Portugis dari Maluku.

Sultan Alauudin (Kerajaan Goa), sangat menentang tindakan Belanda secara terang-terangan. Ia meninggal pada tahun 1639 , dan digantikan oleh anaknya yang bernama Sultan Muhammad Said. Ia mengirimkan armada laut ke Maluku untuk melawan Belanda. Ia meninggal pada tahun 1653. Perlawanan Makasar terhadap Belanda memuncak pada masa pemerintahan Sultan Hasanuddin (1653-1669). Perlawanan Makasar terhadap Belanda memuncak pada masa pemerintahan Sultan Hasanuddin (16531669). Hasanuddin merupakan Raja Makasar yang paling berani melawan Belanda, sehingga mendapat julukan "Ayam Jantan dari Timur". Ia sering melakukan penyerangan terhadap kapal-kapal Belanda, yang sangat merugikan VOC (Belanda).

Pada tahun 1602 para pengusaha Belanda memonopoli perdagangan rempah-rempah membentuk kongsi dagang VOC (Vereenigde Oost-Indische Compagnie) yang pada tahun 1800 mengalami kebangkrutan digantikan oleh pemerintah Belanda. Tak ayal lagi, sistem hukum yang dibangun diatasnya berkecamuk gaya pemikiran Eropa Barat. Pada periode ini, hukum nampaknya berkutat dalam kubangan ideologis, antara liberalis, sosialis, atau pro-status quo penguasa kolonial.

Soetandyo ${ }^{6}$ mencoba memetakan perkembangan hukum Indonesia ke dalam tiga periode besar: 1840-1890, 1890-1940, dan 1940-1990. Tahun 1840 dipilihnya sebagai awal kajian, karena dasawarsa tahun 1840 ini adalah dasawarsa dimulainya realisasi kebijakan-kebijakan kolonial yang baru sehubungan dengan bermulanya secara nyata kemenangan ide-ide liberal dalam politik pemerintahan di Belanda. Periode pertama ini merupakan perkembangan yang sangat dipengaruhi oleh kebijakan-kebijakan liberalisme. Periode kedua merupakan periode ketika kebijakan kolonial sangat dipengaruhi oleh politik etis pemerintah. Sedangkan tahun-tahun 1940-1990 merupakan langkah dekolonisasi, di mana para pemimpin bangsa berjuang untuk menentukan nasibnya sendiri.

Hingga akhirnya tiba saatnya pada penjelajahan pemikiran putra nusantara sendiri yang dimotori oleh dua tokoh pemikir hukum Indonesia, yakni Soepomo dan Soekanto. Kedua tokoh ini mengalami problem yang sama saat ilmu yang mereka dapatkan tak lain adalah produksi pemerintahan kolonial. Meskipun mereka berkilah dengan semangat nasionalisme dan pro-inlander, namun tetap saja, rujukan-rujukan yang dipakai masih sarat akan situs warisan kolonial. Semangat nasionalisme ditunjukan oleh pemikiran hukum awal kemerdekaan ini dengan menitik beratkan pada spirit antikolonialisme. Soekanto dan Soepomo memiliki corak yang sama memperlakukan ilmu hukum Indonesia pada tahapan embrio ini. Ilmu hukum memiliki telos (tugas kebudayaan) membangun kedaulatan kemerdekaan bangsa Indonesia seutuhnya, lepas dari anasir-anasir penjajahan.

Setelah perkembangan ilmu hukum zaman kemerdekaan lebih diorientasikan untuk pembangunan sistem hukum darurat sebagai bangsa yang berdaulat. Pada tahun 1950-an sudah terjalin beberapa embrio pengembangan keilmuan hukum. Dari sinilah, pendekatan empiris yang mengobar-kobarkan semangat hukum adat mendapat lawan bicaranya, yang kelak malah menjadi hukum paling dominan di perhelatan dunia pemikiran hukum Indonesia. Tumbuh kembangnya aliran hukum positivistik di Indonesia merupakan sebuah perkembangan kearah keilmuan hukum yang memegang teguh penalaran 'saintis'disiliplin hukum.

Pada era tahun 60-an awal, tepatnya 11 Maret 1963 digelarlah seminar hukum nasional pertama oleh Lembaga Pembinaan Hukum Nasional. Forum ilmiah ini tidak terlepas dari kepentingan rejim orde lama dalam memasukan ideologinya dalam pembangunan hukum nasional. Hukum digunakan sebagai alat untuk kepentingan revolusi, hukum hanya sebuah metode pemurnian ideologi negara menjamin keberlangsungan revolusi sosial. Karena kepentingan pembangunan saat itu menjadi primadona dalam pemerintahan orde baru, maka hukum negara diperuntukan bagi memperlancar proyek pembangunan melalui Repelita.

Pada masa orde baru ilmu hukum dipersembahkan pada pembangunan fisik dan ekonomi. Maka ilmu hukum dalam kerangka logika positivistik cukup diminati yang lebih fokus pada strukturasi dan formalisme yang menghadirkan ketertiban dan stabilitas nasional. Hingga tiba pada puncaknya hukum positivistik sebagai panglima yang menfasilitasi pembangunan nasional saat Mochtar Kusumaatmadja menduduki jabatannya sebagai Menteri Kehakiman (28 Maret 1973-29 Maret 1978). Pada masanya, hukum memang digunakan sebagai alat perubahan sosial (law as tool of social engineering). Pada masa inilah hukum sesuai dengan fungsinya terebut diarahkan sebagai sarana pembangunan di segala bidang yang di wadahi dalam bentuk haluan negara yang disebut Garis-Garis Besar Haluan Negara dalam setiap Rencana Pembangunan Lima Tahun (Repelita). Era Orde Baru ini bertahan hingga tahun 1998 masih dengan kepemimpinan Presiden Soeharto (sekitar 32 tahun berkuasa).

\footnotetext{
${ }^{6}$ Wignjosoebroto, Soetandyo, Dari Hukum Kolonial ke Hukum Nasional :Dinamika Sosial-Politik dalam perkembangan hukum di Indonesia $1840-1990$ (Jakarta: Rajawali Press, 1995), hlm. 70-80.
} 
JKPIs, Vol. 1 No. 1, 2018 | 31

Orde Baru jatuh pada tanggal 21 Mei 1998 yang ditandai dengan jatuhnya Presiden Soeharto dengan meyerahkan kekuasaan kepada Wakil Presiden BJ Habibie. Tuntutan terhadap pebaikan pemerintahan negara terus didorong dan dimulailah era baru yang disebut Era Reformasi. Pada era reformasi, berbagai tuntutan perubahan dalam penyelenggaraan negara diajukan. Konstitusi diubah dengan mengamandemen UUD sebanyak 4 tahap. Inti dari amandemen tersebut, yaitu; ${ }^{7}$

1. Perubahan pertama (disahkan 19 Oktober 1999) memuat pergeseran kekuasaan Presiden yang dipandang terlampau kuat(executive heavy);

2. Perubahan kedua (disahkan 18 Agustus 2000): Pemerintah Daerah, DPR dan Kewenangannya, Hak Asasi Manusia, Lambang Negara dan Lagu Kebangsaan;

3. Perubahan ketiga (disahkan 10 November 2001): Bentuk dan Kedaulatan Negara, Kewenangan MPR, Kepresidenan, Impeachment, Keuangan Negara, Kekuasaan Kehakiman;

4. Perubahan keempat (disahkan10 Agustus2002): DPD sebagai bagian MPR, Penggantian Presiden, pernyataan perang, perdamaian dan perjanjian, mata uang, bank sentral, pendidikan dan kebudayaan, perekonomian nasional dan kesejahteraan sosial, perubahan UUD.

Adapun politik hukum dalam perubahan konstitusi adalah sebagai berikut:

1. Mengurangi kekuasaan Presiden dengan cara mendistribusikan kekuasaan secara vertikal dan membagikan kekuasaan secara horisontal;8

2. Mengubah kekuasaan yang sentralistik ke arah desentralistik;

3. Meningkatkan peran DPR melakukan pengawasan terhadap kekuasaan eksekutif;

4. Mengubah struktur keanggotaan MPR dan menggunakan sistem bikameral dalam pembuatan UU;

5. Mengembalikan hak atas kedaulatan rakyat dengan pemilu langsung; 6) Menjaga kekuasaan yang seimbang dengan menerapkan mekanisme"check and balance system";

6. Menata kembali sistem peradilan dan pranata lunak untuk memulihkan kepercayaan pencari keadilan; dan

7. Konstitusi yang rinci memuat HAM, kewajiban penyelenggara negara dan pembatasan/pengendalian kekuasaan (Soewoto Mulyosudarmo, 2004: 40).

Dalam perspektif politik hukum, produk hukum sangat dipengaruhi bahkan ditentukan oleh pemegang kekuasaan politik, maka konstruksi politik setiap penguasa akan mempengaruhi corak dan karakter hukum. Terkait dengan pandangan ini perspektif ini, Mahfud (2001: 15) telah melakukan penelitian dengan berangkat dari asumsi bahwa konfigurasi politik suatu negara akan melahirkan karakter produk hukum tertentu di suatu negara. Negara yang konfigurasi politiknya demokratis akan melahirkan produk hukum yang berkarakter responsif/populistik, sedangkan di negara yang konfigurasi politiknya otoriter, maka produk hukumnyaakan bersifat fluktuatif dengan karakter ortodoks/konservatif/elitis.

Terhadap perkembangan hukum positif di Indonesia ini, para pemikir hukum berkeyakinan bahwa sebagai negara bekas jajahan Belanda, hukum nasional Indonesia tidak dapat melepaskan diri dari proses transplantasi hukum Belanda, bahkan hingga sekarang sesudah 72 tahun Indonesia merdeka sekalipun. Oleh karenanya, hukum positif di Indonesia secara otomatis sangat bercorak Eropa-centris, Belanda. Padahal, masyarakat pribumi tentu saja memiliki pemikiran orisinal terkait produk hukumnya sendiri jauh sebelum kolonial datang. Perlu diingat pula bahwa perkembangan hukum di Indonesia lebih banyak ditentukan oleh perkembangan hukum yang dimaknai secara professional atau lawyer's law, khususnya yang sangat kental dengan paradigma positivism.

\section{KOMPARASI SISTEM HUKUM POSITIF DENGAN SISTEM HUKUM ISLAM}

\subsection{Persamaan antara Islam dan Demokrasi}

Uraian berikut ini dikutip dari pendapat Dr. Dhiyauddin ar Rais yang sebutkan dalam artikel Habib Arifin di blogspotnya. ${ }^{9}$ Ar Rais menyatakan bahwa ada beberapa hal persamaan yang mempertemukan Islam dan demokrasi. Namun, perbedaannya lebih banyak. Persamaannya menyangkut pemikiran sistem politik tentang hubungan antara umat dan penguasa serta tanggung jawab pemerintahan. Akhirnya, Ar Rais sampai pada kesimpulan bahwa antara Islam dan demokrasi tidak hanya memiliki persamaan di bidang politik. Lebih dari itu, unsur-unsur yang terkandung dalam demokrasi dan keistimewaannya pun sudah terkandung di dalam Islam. Dalam menerangkan hal itu, Ar Rais menyatakan:

1) Jika yang dimaksud dengan demokrasi seperti definisi Abraham Lincoln: democracy is government of the people, by the people and for the people (dari rakyat, oleh rakyat dan untuk rakyat) pengertian itu pun ada di dalam sistem negara Islam dengan pengecualian bahwa rakyat harus memahami Islam secara komprehensif.

2) Jika maksud demokrasi adalah adanya dasar-dasar politik atau sosial tertentu (misalnya, asas persamaan di hadapan undangundang, kebebasan berpikir dan berkeyakinan, realisasi keadilan sosial, atau memberikan jaminan hak-hak tertentu, seperti hak hidup dan bebas mendapat pekerjaan). Semua hak tersebut dijamin dalam Islam.

3) Jika demokrasi diartikan sebagai sistem yang diikuti asas pemisahan kekuasaan, itu pun sudah ada di dalam Islam. Kekuasaan legislatif sebagai sistem terpenting dalam sistem demokrasi diberikan penuh kepada rakyat sebagai satu kesatuan dan terpisah dari kekuasaan Imam atau Presiden. Pembuatan Undang-Undang atau hukum didasarkan pada Al-Quran dan Hadist, Ijma', atau Ijtihad. Dengan demikian, pembuatan UU terpisah dari Imam, bahkan kedudukannya lebih tinggi dari Imam. Adapun Imam harus menaatinya dan terikat UU. Pada hakikatnya, Imamah (kepemimpinan) ada di kekuasaan eksekutif yang

\footnotetext{
${ }^{7}$ Sauqi Futaqi, Perkembnagan dan Pergeseran Hukum Nasional, Jurnal Mlangi Volume 1, No. 3, Nov 2013 -Feb 2014.

${ }^{8}$ Pembaharuan ketatanegaraan melalui perubahan konstitusi. Authors, Suwoto Mulyosudarmo, Abdul Mukthie Fadjar, Harjono. Publisher, Asosiasi Pengajar HTN dan HAN Jawa Timur dan In-TRANS,2004.

${ }^{9}$ http://habibiarifin.blogspot.co.id/2010/05/demokrasi-islam.html. Sumber utama tulisan ini adalah Makalah dari Achmad Zain Nurrudin, Mahasiswa IAIN Sunan Ampel Surabaya yang berjudul Islam dan Demokrasi Dalam Praktik Politik Indonesia, 28 Nopember 2010.
} 
JKPIs, Vol. 1 No. 1, 2018 | 32

memiliki kewenangan independen karena pengambilan keputusan tidak boleh didasarkan pada pendapat atau keputusan penguasa atau presiden, jelainkan berdasarka pada hukum-hukum syariat atau perintah Allah Swt.

\subsection{Perbedaan antara Islam dan Demokrasi}

Di samping terdapat persamaan, antara demokrasi dan Islam memiliki berbagai perbedaan mendasar. Menurut Dhiyauddin Ar Rais, ada tiga hal yang membedakan sistem Islam dan sistem demokrasi, yaitu:10

“Pertama, dalam demokrasi yang sudah populer di Barat, definisi bangsa atau umat dibatasi batas wilayah, iklim, darah, sukubangsa, bahasa dan adat-adat yang mengkristal. Dengan kata lain, demokrasi selalu diiringi pemikiran nasionalisme atau rasialisme yang digiring tendensi fanatisme. Adapun menurut Islam, umat tidak terikat batas wilayah atau batasan lainnya. Ikatan yang hakiki di dalam Islam adalah ikatan akidah, pemikiran dan perasaan. Siapa pun yang mengikuti Islam, ia masuk salah satu negara Islam terlepas dari jenis, warna kulit, negara, bahasa atau batasan lain. Dengan demikian, pandangan Islam sangat manusiawi dan bersifat internasional.

Kedua, tujuan-tujuan demokrasi modern Barat atau demokrasi yang ada pada tiap masa adalah tujuan-tujuan yang bersifat duniawi dan material. Jadi, demokrasi ditujukan hanya untuk kesejahteraan umat (rakyat) atau bangsa dengan upaya pemenuhan kebutuhan dunia yang ditempuh melalui pembangunan, peningkatan kekayaan atau gaji. Adapun demokrasi Islam selain mencakup pemenuhan kebutuhan duniawi (materi) mempunyai tujuan spiritual yang lebih utama dan fundamental.

Dapat pula dikatakan akad atau transaksi kepemimpinan dalam demokrasi itu murni akad ijaroh (transaksi kerja). Dimana politisi dianggap bekerja untuk rakyat melalui kontrak sosial via pemilu dan Pilkada. Karena ruh nya bekerja, wajar saja jika politisi dan pejabat mencari upah (ujroh) yang besar dari pekerjaan yang dilakukannya baik dari gaji maupun melalui korupsi.

Ketiga, kedaulatan umat (rakyat) menurut demokrasi Barat adalah sebuah kemutlakan. Jadi, rakyat adalah pemegang kekuasaan tertinggi tanpa peduli kebodohan, kezaliman atau kemaksiatannya. Namun dalam Islam, kedaulatan rakyat tidak mutlak, melainkan terikat dengan ketentuan-ketentuan syariat sehingga rakyat tidak dapat bertindak melebihi batasan-batasan syariat, Al-Quran dan As-Sunnah tanpa mendapat sanksi."

Dengan kata lain, demokrasi meletakan kedaulatan ada ditangan rakyat sehingga proses produksi hukum dan perundangundangan itu bersifat kompromistis yang rawan diperdagangkan. Hukum itu kesepakatan politik, bukan halal haram. Dalam Islam kedaulatan hukum ada ditangan Syara. Jika Allah telah menetapkan suatu perbuatan itu haram, maka Khalifah tidak boleh mengubahnya.

Menurut sistem Islam, kekuasaan tertinggi bukan di tangan penguasa karena Islam tidak sama dengan paham otokrasi. Kekuasaan bukan pula di tangan tokoh-tokoh agamanya karena Islam tidak sama dengan teokrasi. Begitupun bukan di tangan UU karena Islam tidak sama dengan nomokrasi atau di tangan umat karena Islam bukan demokrasi dalam pengertian yang sempit. Jawabannya, kekuasaan tertinggi dalam Islam sangat nyata sebagai perpaduan dua hal, yaitu umat dan undang-undang atau syariat Islam. Jadi, syariat pemegang kekuasaan penuh dalam negara Islam. Dr. Dhiyauddin Ar Rais menambahkan, jika harus memakai istilah demokrasi tanpa mengabaikan perbedaan substansialnya sistem itu dapat disebut sebagai demokrasi yang manusiawi, menyeluruh (internasional), religius, etis, spiritual, sekaligus material. Boleh pula disebut sebagai demokrasi Islam atau menurut al Maududy demokrasi teokrasi.

Salah satu hal esensi sistem pemerintahan demokrasi adalah suksesi kepemimpinan nasional diselenggarakan melalui pemilu. Terdapat perbedaan Pemilu dalam sistem Khilafah dengan Pemilu dalam sistem Demokrasi. Disebutkan bahwa, ketika Islam membolehkan Pemilu untuk memilih khalifah atau anggota majelis umat, bukan berarti Pemilu dalam Islam identik dengan Pemilu dalam sistem demokrasi sekarang. Dari segi cara/teknis (uslûb), memang boleh dikatakan sama antara Pemilu dalam sistem demokrasi dan Pemilu dalam sistem Islam (An-Nabhani, At-Tafkîr, 1973: 91-92; Urofsky, Demokrasi, 2003: 2). Namun demikian, dari segi falsafah dasar, prinsip, dan tujuan keduanya sangatlah berbeda; bagaikan bumi dan langit. Beda antara pemuilu dalam demokrasi dan Pemilu dalam Islam sebagai berikut:

Pertama, Pemilu dalam demokrasi didasarkan pada falsafah dasar demokrasi itu sendiri, yaitu pemisahan agama dari kehidupan (fashl al-dîn 'an al-hayâh, secularism) (Al-Khalidi, 1980: 44-45), sedangkan Pemilu dalam Islam didasarkan pada akidah Islam, yang tidak pernah mengenal pemisahan agama dari kehidupan (Yahya Ismail, 1995: 23). Kedua, Pemilu dalam sistem demokrasi didasarkan pada prinsip kedaulatan di tangan rakyat (as-siyâdah li asy-sya'b), sehingga rakyat, di samping mempunyai hak memilih penguasa, juga berhak membuat hukum. Sebaliknya, Pemilu dalam Islam didasarkan pada prinsip kedaulatan di tangan syariat (as-siyâdah li asy-syar'î), bukan di tangan rakyat. Jadi, meskipun rakyat berhak memilih pemimpinnya, kehendak rakyat wajib tunduk pada hukum al-Quran dan as-Sunnah. Rakyat tidak boleh membuat hukum sendiri sebagaimana yang berlaku dalam demokrasi (An-Nahwi, 1985: 37-38; Ash-Shawi, 1996: 69-70; Rais, 2001: 311). Ketiga, tujuan Pemilu dalam sistem demokrasi adalah memilih penguasa yang akan menjalankan peraturan yang dikehendaki dan dibuat oleh rakyat. Sebaliknya, Pemilu dalam Islam bertujuan untuk memilih penguasa yang akan menjalankan Kitabullah dan Sunnah Rasul-Nya, bukan menjalankan hukum kufur buatan manusia seperti dalam demokrasi (Zallum, 1990: 1, 1994: 139-140; Belhaj, $1411: 5$ ).

Berdasarkan uraian di muka dapat dinyatakan bahwa pemilu dalam sistem Khilafah, walaupun ada kemiripan, tetap tidak sama dengan pemilu dalam sistem demokrasi saat ini. Ibaratnya adalah seperti babi dan sapi. Keduanya memang ada kemiripannya, misalnya sama-sama berkaki empat. Tapi yang pertama haram sedang yang kedua halal. Perbedaan-perbedaan pemilu dalam sistem demokrasi dan khilafah itulah yang wajib kita cermati, agar kita tidak terjerumus dalam dosa karena ikut-ikutan terlibat dalam praktik sistem demokrasi yang kufur.

\section{ALTERNATIF SOLUSI MENJADIKAN HUKUM ISLAM SEBAGAI SUMBER HUKUM UTAMA NEGARA}

\footnotetext{
${ }^{10}$ sumber tulisan: http://habibiarifin.blogspot.co.id/2010/05/demokrasi-islam.html. lihat juga https://fillah.wordpress.com/2007/06/25/persamaan-dan-perbedaan-sistem-politik-islam-dan- demokrasi).
} 
Teoretisi sosial abad 19, A. de Tocqueville dan Toennies menyatakan bahwa penyebab kerusakan masyarakat sistemis adalah kapitalisme atau industrialisasi. Kerusakan sistemis itulah yang kemudian membentuk yang mereka sebut mass society (masyarakat massa). Konsep mass society menyatakan bahwa masyarakat kontemporer memiliki karakteristik sebagai berikut: 11

1. Kebanyakan individu serupa, setara dan tidak terdiferensiasi, menunjukkan tidak ada individualitas;

2. Pekerjaan rutin dan mengasingkan;

3. Agama telah kehilangan pengaruhnya dan tidak ada nilai-nilai moral yang dipegang teguh, meskipun massa cenderung pada fanatisme ideologis;

4. Hubungan antar individu lemah dan sekunder, ikatan kekeluargaan menjadi tidak penting;

5. Massa apatis secara politik dan mudah dimanipulasi oleh kediktaktoran dan birokrasi;

6. Kebudayaan --seni, sastra, filsafat dan ilmu pengetahuan-- telah menjadi budaya massa: yaitu, direduksi ke tingkat selera rendah.

Melihat fakta yang ada di era sekarang ini, tampak terkesan banyak orang nyaman terjebak dalam kerangkeng mass society.

1. Kalau dulu, hubungan antar individu itu erat, zaman now kita lebih nyaman dalam hubungan yang longgar, hingga menyeruak masuk ke dalam rumah tangga dengan hubungan kekeluargaan yang sangat rapuh;

2. Kalau dulu agama sangat memiliki pengaruh yang kuat dalam setiap pengambilan keputusan informal masyarakat maupun formal kenegaraan, zaman sekarang kita lebih nyaman dengan sekularisasi. Urusan dunia harus dipisahkan dengan urusan akhirat. Politik harus dipisahkan dari agama. Agama tidak boleh mengintrusi urusan politik sehingga dalam demokrasi tidak dikenal halal haram, dan hanya mengadopsi pemikiran-pemikiran Barat yang sudah jelas condong ke liberal-kapital. Hukum pun seolah terlepas dari watak transendensi-nya, yakni hukum yang seharusnya menjadikan agama sebagai panutan dan bintang pemandu. Namun, hukum sekarang ini menjadi sangat profan nan sekular, dan itu menjadi bahan utama penegakan hukum di Indonesia ini. Bukalah mata dan pikiran kita, penegakan hukum sekarang yang berhati nurani semakin dilumpuhkan bahkan ulama dijerat dan kemudian dikandangkan dengan tuduhan radikalisme atau sekadar dijerat dengan rumusan ujaran kebencian yang sarat dengan kepentingan ambigu;

3. Kalau dulu massa tidak apatis terhadap politik, namun zaman sekarang akibat distrust yang akut menyebabkan massa menjadi apatis, mereka tidak mau tau serta hopeless terhadap proses hingga hasil politik. What will be will be! Kalau dulu dengan kesadarannya massa sulit untuk dimanipulasi oleh kediktaktoran dan birokrasi, sekarang kita terkesan nyaman dan dengan sukarela mau dimanipulasi untuk memuluskan kepentingan politik tertentu sehingga birokrasi pun dipakai sebagai kendaraan untuk mempertahankan dan memperjuangkan vested interest. Birokrasi mana yang dijamin kenetralannya sekarang ini?

4. Kalau dulu seni termasuk di dalamnya ilmu pengetahuan itu dianggap dan ditempatkan sebagai karya mulia anak manusia sehingga memiliki nilai yang adiluhung sehingga mampu mencerahkan dan makin mendekatkan kepada yang maha indah, sekarang seni terasa miskin akan makna adiluhung itu, justru nilai itu direduksi ke tingkat selera rendah. Ilmu pengetahuan telah kehilangan ruhnya, yakni pencarian kebenaran. Kebenaran ilmu banyak yang disembunyikan demi kepentingan pribadi karena kita lebih menyukai berada di zona nyaman meski nir-kebenaran. Kebenaran dan keadilan tidak ada karena banyak ilmuan yang takut mengatakan kebenaran di tengah kediktaktoran rezim dan birokrasi.

Andai pribadi anggota masyarakat ini tidak terjebak dalam mass society seperti ini, tentu bangsa ini tidak semakin tersingkir di masa kini dan terpuruk di masa depan. Mass society harus segera "diruwat" dan diakhiri dengan madany society. Masyarakat yg setara, adil, pemerintahannya diselenggarakan dengan daulat rakyat yang beriman kepada Tuhan Alloh. Bila perpolitikan kita dan cara berhukum kita selalu menengok ke Barat, maka akan saya beritakan mengenai seorang filsuf Italia yang bernama Thomas Aquinas (1224-1274 M). Thomas Aquinas mengajukan beberapa pemikiran yang berbeda pada kebanyakan filsuf lain yang menegasikan adanya "mistisisme". Salah satu pemikiran tersebut dapat saya konkritkan menjadi "KITAB SUCI DI ATAS KONSTITUSI" (Thomas Aquinas) yang akan dibahas ahli setelah ini. Dengan cara apalagi kalau bukan kita lakukan perubahan mendasar dengan berpikir dan bertindak secara RADIKAL bukan GRADUAL yang melelahkan. Berpikir secara radikal berarti berpikir mengakar, mendasar bahkan di luar konteks, menjadi manusia yang bebas dan mengerti hakikat sesuatu tanpa terkungkung oleh hukum tekstual yang berlandaskan liberal-kapitalis tersebut. Revolusi PERILAKU di bidang hukum dan politik diperlukan bukan sekadar reformasi apalagi cuma sekadar evolusi. Ahli merasa yakin pada satu prinsip bahwa:

\section{"Hanya Dengan Perilaku Baik Hukum Dan Politik Akan Menjadi Baik"}

Pertanyaannya adalah siapa yang mampu membuat manusia berperilaku baik? Atau kita dapat menanyakan dengan sarana apakah yang bisa membingkai, mengarahkan agar perilaku manusia menjadi baik?

Sebagai homo homini socius, manusia tidak dapat hidup sendiri dan memenuhi semua kebutuhannya sendiri tanpa berhubungan dengan manusia yang lain. Mereka berinteraksi, berkumpul membentuk keluarga, masyarakat, bangsa hingga terbentuklah suatu negara. Manusia menegara. Manusia menegara memiliki tujuan nasionalnya, bahkan tujuan internasional. Menurut Rosseu, bila ditinjau dari teori kontrak sosial, maka terbentuknya suatu negara-bangsa tentu membutuhkan kesepakatan yang dalam negara demokrasi ditempuh dengan cara menjajagi volonte de tous (kehendak setiap orang) untuk menemukan volonte generale (kehendak semua orang). Di sinilah kita menemukan adanya HUKUM. Bila didasarkan pada pendapat Paul Bohanan, maka hukum yang disepakati oleh warga negara-bangsa itu merupakan reinstitusionalisasi (pelembagaan kembali) atas nilai-nilai hukum serta rasa keadilan yang telah ada atau hidup di dalam masyarakat. Nilai hukum dan rasa keadilan dalam masyarakat itu dapat berupa nilai hukum agama maupun nilai hukum kebiasaan. Oleh karena suatu negara juga berhubungan dengan negara lain, maka nilai hukum juga meluas pada nilai hukum yang mondial, misalnya nilai hukum modern. Oleh karena itulah bahan untuk membangun hukun suatu negara bangsa dapat berupa bahan nilai hukum kebiasaan, nilai hukum agama dan nilai hukum internasional.

\footnotetext{
${ }^{11}$ Nicholas Abercrombi dkk, Kamus Sosiologi, Penerjemah Desi Noviyani dkk, Pustaka Pelajar, Yogyakarta, 2010, hlm. $335-226$.
} 
Indonesia sebagai negara bangsa oriental, tidak lepas dari pengaruh baik maupun buruk atas perkembangan global. Namun sangat disadari Indonesia memiliki dasar pengembangan negara bangsa untuk mencapai cita-cita atau tujuan nasionalnya. Dasar itu tidak lain adalah Pancasila. Bila kita simak secara saksama, maka ketiga nilai hukum itu sebenarnya telah terkandung dalam Pancasila, yaitu nilai ketuhanan--dikatakan sebagai dasar dan meliputi dari segala sila, nilai hukum kebiasaan (persatuan, demokrasi, kesejahteraan) serta nilai hukum internasional (kemanusiaan, HAM). Ketiga nilai hukum tersebut kemudian mengejawantah menjadi kesepakatan membentuk NEGARA BERDASAR HUKUM (Pasal 1 ayat 3 UUD NRI 1945). Macam apa negara hukum yang hendak kita bangun itu? Negara hukum yang hendak dibangun itu adalah negara hukum yang berdasarkan atas KETUHANAN YANG MAHA ESA (Pasal 29 ayat (1) UUD NRI 1945). Lebih konkret lagi negara hukum itu adalah NEGARA HUKUM TRANSENDENTAL. Dari sini dulu kita harus memahami dan mengingat betul konsep dasar dari suatu negara, baru setelah itu membicarakan hal-hal teknis yang lainnya.

Sebagai negara hukum transendental, menurut Thomas Aquinas ${ }^{12}$ maka hukum yang direproduksi kembali melalui lembagalembaga supra dan infra struktur negara (HUMAN LAW) seharusnya dijiwai nilai ketuhanan baik nilai hukum ketuhanan yang tertulis di KITAB SUCI / DEVINE LAW (eternal law that revealed in scripture), maupun nilai hukum ketuhanan yang melekat pada alam (HUKUM ALAM/NATURAL LAW (eternal law that discovered through human reason)). Sampai di sinilah secara logika sederhana pun kita bisa memahami dan menerima secara nalar bahwa KITAB SUCI itu berada di atas KONSTITUSI sebagaimana telah disebutkan di muka. Bila penalaran ini kemudian kita tarik garis lurus, maka logikanya seharusnya disadari bahwa KONSTITUSI dan TURUNANNYA tidak boleh bertentangan dengan KITAB SUCI. Juga dapat kita nalar bahwa membaca, mengkaji, memahami, menjalankan bahkan menyebarkan (mendakwahkan) perintah Tuhan dalam KITAB SUCI yang kebenarannya tidak perlu diragukan adalah sebuah kebolehan bahkan sebuah kewajiban bagi para pemeluknya. Inilah yang kita sebut dalam Islam: AMAR MA'RUF NAHI MUNKAR. Hal ini justru juga dilindungi oleh negara melalui Konstitusi, yakni Pasal 28D (1) dan 29 ayat 2 UUD 1945 yang pada intinya menegaskan bahwa setiap orang bebas untuk memeluk agama dan beribadat menurut agamanya, juga berhak atas kebebasan meyakini kepercayaan, menyatakan pikiran dan sikap, sesuai dengan hati nuraninya.

Dengan penjelasan Thomas Aquinas tersebut di muka, maka kita harus membuka mata kita (kembali) bahwa kita harus menjadi manusia yang mengutamakan ajaran langit, karena itu apa yang kita bawa sejak lahir dan kita ingin wafat dengan tetap memegang teguh agama Islam harus selalu dipegang teguh. Kemerdekaan untuk memeluk, beribadah sesuai dengan agama dan kepercayaan sangat dilindungi sebagai HAM yang tidak dapat dikurangi (non derogable human rights). Jadi, pelarangan, penghambatan, pencabutan Badan Hukum bahkan pembubaran organisasi masa yang dijamin pembentukannya serta kegiatannya yang sah adalah sebuah pelanggaran HAM yang nyata.

\section{KESIMPULAN}

Cicero mengatakan bahwa ubi societas ibi ius, di mana ada masyarakat di situ ada hukum. Ini secara teoretik berarti setiap masyarakat itu mempunyai hukumnya sendiri, yakni hukum yang terbentuk bisa jadi sangat berbeda dengan hukum masyarakat lainnya. Perkaitan antara hukum dan struktur sosial sangat erat. Transformasi hukum menjadi sebuah perkara yang cukup pelik dan rumit ketika kedua hal tersebut saling berkelindan, antara struktur sosial dan hukum, Pada tahun 1970, William J. Chambliss dan Robert B Seidman melakukan penelitian bagaimana pengaruh lembaga informal terhadap bekerjanya hukum di negara Afrika, hingga sampai pada suatu dalil yang cukup terkenal yaitu: The law of non transferability of law (Dalil tidak dapat dialihkannya hukum begitu saja). Oleh karena itu trasformasi hukum termasuk pemerintahan demokrasi menuju sistem (hukum) pemerintahan Islam dibutuhkan landasan yakni filosofis, yuridis, sosiologis dan juga politis. Perbandingan hukum Islam dengan hukum nasional demokrasi sangat mendasar terutama terkait dengan (1) cakupan wilayah dan ikatan hubungan; (2) landasan dan tujuan; (3) kedaulatan umat (rakyat).

Meskipun hukum adat yang mencirikan khas keindonesiaan pernah menjadi salah satu tawaran terbaik, pada kenyataannya juga masih mudah terjebak pada paradigma yang lama, yakni positivisme hukum. Kalau pun hukum adat, dan mungkin hukum Islam dengan berbagai nilai keadilan yang dimilikinya, dikembangkan menjadi hukum nasional, ia tidak semestinya terjebak pada paradigma positivistik-legalistik-formalistik, yang menempatkan hukum sebagai benda mati. Secara teoretis memang sangat dimungkinkan hukum Islam sebagai sumber hukum utama dalam pembangunan dan pengembangan hukum di Indonesia, namun secara praktis hukum Islam hanya dijadikan landasan untuk mengatur hukum keluarga saja, sedangkan untuk hukum publik tidak dijadikan sumber secara langsung. Hukum Islam akan menjadi sumber utama hukum bila negara itu memiliki sistem pemerintahan Islam, tidak lain SISTEM KHILAFAH.

\section{REFERENSI}

Abercrombi, N. (2010). Kamus Sosiologi, Penerjemah Desi Noviyani dkk. Yogyakarta: Pustaka Pelajar.

Cavendish. (1997). Cavendish Law Cards Juriprudence, London: Cavendish Publishing Limited.

Futaqi, S. (2013). Perkembnagan dan Pergeseran Hukum Nasional, Jurnal Mlangi 1(3).

Mahfud, M.D. (2001). Politik Hukum di Indonesia. Jakarta: LP3ES.

Mulyosudarmo, S., Fadjar, A.M., Harjono. (2004). Pembaharuan ketatanegaraan melalui perubahan konstitusi. Surabaya: Asosiasi Pengajar HTN dan HAN Jawa Timur dan In-TRANS.

Soetandyo, w. (1995). Dari Hukum Kolonial ke Hukum Nasional :Dinamika Sosial-Politik dalam perkembangan hukum di Indonesia 1840-1990. Jakarta: Rajawali Press.

Tantular, M. (2009). Kakawin Desa Warnnana Uthawi Nāgara Krtāgama. Diterjemahkan oleh Prof. Dr. Drs. I Ketut Riana, SU. Masa Keemasan Majapahit. Jakarta: Kompas.

\footnotetext{
${ }^{12}$ Cavendish Publishing Limited, Cavendish Law Cards Juriprudence, London, 1997, hlm 25-26.
} 